\title{
Den humanitære livsform - en ny epistemologi for den professionelle etos i velfærdsarbejde
}

\author{
Bjørn Ribers
}

Denne artikel udbygger og nuancerer livsformsanalysen ved at introducere og definere en ny livsformskategori, den humanitære livsform, og belyse hvordan den er sammenvævet med professionsbegrebet, og udsprunget af velfærdsprofessionernes arbejde og placering i staten. På baggrund af et årtis forskning i velfærdsarbejde og professionsetik diskuteres den kompleksitet, som kendetegner velfærdprofessionernes arbejdsliv og eksistensmodus. Begrebet den humanitære livsform er opstået som en ny forskningsbaseret konceptualisering, forankret i livsformsanalysen, som i samspil med professionsforskning og forskning i professionsetik belyser, hvordan livsformer og professionsidentieter er i udvikling. Artiklen diskuterer dynamikken og kompleksiteten i den triade det er at være et menneske, der samarbejder med mennesker, for og om mennesker. Nyere forskning viser, hvordan der opstår etiske dilemmaer og dikotomier mellem professionsetiske fordringer og velfærdsprofessionernes vilkår i konkurrencestaten. Den humanitære livsform indebærer professionsetisk bevidsthed som et essentielt bærende element for professionel integritet og som klangbunden for faglighed i professionelt velfærdsarbejde med fokus på at skabe det gode liv.

Nøgleord: Den humanitære livsform, professionsetik, velfærdsprofessioner, velfærdslivsformer, eudaimoni, den professionelle etos

\section{Den humanitære livsform og velfærdslivsformerne}

Med livsformskategorien, den humanitære livsform, etableres i denne artikel en ny epistemologi for den professionelle etos $\mathrm{i}$ velfærdsarbejde. Konceptualisering belyser den kompleksitet, som kendetegner velfærdprofessionernes arbejde - og artiklen er således begrebsskabende på baggrund af eksisterende forskning. Livsformerne er en overordnet kategori og ikke synonyme med professionerne eller med menneskers etiske perspektiver i professionelle og arbejdsmæssige sammenhænge, men afspejler i højere grad dybt forankrede værdier, der former menneskers identiteter via kategoriseringer og dikotomier mennesker imellem. Den humanitære livsform er således en udbygget begrebsliggørelse i livsformsanalysen, med fokus på de specifikke sociokulturelle segmenter i samfundet, som blandt andet betegnes relationsprofessioner, velfærdsarbejdere og det affektive arbejdsfelt. Når man skal beskrive den humanitære livsform, så er 
et karakteristisk træk, at den er nært sammenhængende med professionernes etiske imperativ og de velfærdsprofessionelles etiske bestræbelse. På baggrund af de sidste ti års forskning i velfærdsarbejde og professionsetik - herunder perspektiver på hvordan New Public Management har indflydelse på velfærdsprofessionernes arbejdsliv, samt skaber etisk pres og moral distress (Ribers 2012, 2016a, 2016c, 2018a, 2018b) - vil denne artikel belyse centrale aspekter af professionelles livsverdener og diskutere, hvordan de samlet skaber en humanitær livsform.

Begrebet den humanitære livsform er dermed opstået som en forskningsbaseret kategori - forankret i livsformsanalysen (Højrup 1999, 2003a, 2003b) - som, med udgangspunkt i professionsetikken, indfanger professionsidentiteten og kompleksiteten i den triade det er at være et menneske, der arbejder sammen med mennesker, om mennesker. Begrebsmæssigt sammenkæder Højrup de fundamentale spørgsmål i etikken og de kulturelle og eksistentielle aspekter, der er knyttet til livsformerne:

"Ved at tage udgangspunkt $i$ begrebet det gode liv hos Aristoteles er det først og fremmest muligt at skoerpe vort blik for, at de kulturelle livsformer er eksistensmåder, der bor i staten" (Højrup, 2003, s. 78)

Den humanitære livsform omslutter dermed professionsetisk bevidsthed som et essentielt bærende element for professionel identitet og integritet og som klangbunden for faglighed i professionelt velfærdsarbejde. Empiriske studier af professionelles arbejdsidentitet (Ribers 2012), herunder forståelser af forholdet mellem arbejdsliv, fritidsliv og privatliv, viser, at de tre kategorier, der oprindeligt er udviklet af Højrup (1983a, 1983b, 2003), lønarbejder livsformen, den selvstændige livsform og den karrierebundne livsform, ikke altid fuldgyldigt indfanger velfærdsarbejderes selvforstå- else, professionsidentitet eller placering på arbejdsmarkedet. I den humanitære livsform er der komplekse dynamikker og dimensioner i forholdet mellem arbejdsliv og privatliv, og så er der betydningsfulde oplevelser af at skabe mening på et eksistentielt niveau for mennesker, der lever af humanitært, eller relationsbåret velfærdsarbejde. Denne eksistentielle meningsskabelse i livsverdenen er stærkt forankret i etisk bevidsthed og kan udfordres eller forstyrres af ydre samfundsmæssige og politiske rammer og indflydelse på arbejdslivet.

I en postmoderne optik, er begreber knyttet til psyken og vores selvforståelse, og måden hvorpå vi begriber verden er med til at forankre vores oplevelse af os selv i samfundet, vores faglige identiteter og etiske bevidsthed. Det er med dette teoretiske udgangspunkt, at jeg advokerer for at udvikle kategorien den humanitære livsform. Generelt kategoriseres socialarbejdere, pædagoger, lærere, sygeplejersker og andre velfærdsprofessioner under kategorien lønarbejder-livsformen, men de oprindelige tre livsformskategorier er ikke adækvate til at indfange kompleksiteten af velfærdsprofessionernes arbejde, da relationsarbejde kræver særlige professionsetiske kompetencer, udvikling af moralsk perception, empati og dømmekraft (se Hjort, Kristiansen \& Barkholt, 2018; Krøjer \& Dupret, 2015; Krøjer \& Lehn-Christiansen, 2016; Ribers, 2018a, 2018b).

Livsformer og vilkår behøver ikke at passe sammen (Christensen, 1988); forstået på den måde, at man identitetsmæssigt og strukturelt kan passe til den selvstændige livsform, men være ansat som lønarbejder. Der kan være sammenfaldende eller modsatrettede aspekter af pligt og lyst, af kaldstanke eller samfundsorganisering, som sammenvæves i et konglomerat af personlige og professionelle identiteter, som henholdsvis koeksisterer synkront eller modarbejder hinanden og dermed individet, som er bærer af livsfor- 
men. Buus (2008) introducerer og diskuterer begrebet velfærdslivsform, på en måde hvor sammenhængen mellem professioner og velfærdslivsformer belyses, herunder fagenes professionalisering gennem de sidste årtier. Begrebet den humanitære livsform, med pendanter som menneskearbejder-livsformen eller relationsarbejder-livsformen (Ribers, 2012) afspejler dermed et behov for at diskutere værdien af og kompleksiteten i arbejdet med mennesker og er en ny livsformskategori, som ligger i meningsfuld forlængelse af velfærdslivsformerne. Måske vil en mulig begrebsliggørelse være de humanitære livsformer, i pluralis, da det ikke er tale om en entydig kategori, men flere sidestillede arbejdsformer og livsmåder, der alle har arbejdet med mennesker som genstandsfelt. Livsformerne er ikke niveaumæssigt adskilt, men ligestillede, og kan eksistere og udvikle sig, samtidig med at mennesker reelt kan leve i overlappende livsformskategorier. Det er min tese at livsformerne også vil være i dynamiske og kontinuerlige udviklingsprocesser i hastigt foranderlige samfund, samt at de ikke forbliver statiske eller upåvirkelige kategoriseringer af eksistensmåder i staten (jf. Højrup, 2003).

\section{Eksistensformer og professionelle identiteter}

Forskningsmæssig undersøgelse og analyse af kulturhistoriske processer har belyst kompleksiteten af livsstil, dominans mellem nødvendige betingelser for eksistens og staters politiske, juridiske, ideologiske og økonomiske strukturer (Højrup, 2013). Livsformer kan beskrives som forskelligartede eksistensmodi, båret af egen selvreproducerende praksis og egne begrebsdannelser, som understøtter og vedligeholder verdensbilledet, med en "egen etnocentrisk verdensforståelse, nødvendige relationer til staten og deraf følgende anerkendelse" (Buus 2008, s. 286). Hjort (2019, s.
385) skriver, at det personlige er blevet endnu mere politisk i løbet af de sidste par årtier, hvilket er både positivt og negativt. Samtidig er det politiske også blevet personligt, og etiske beslutninger blevet en uomgængelig del af hverdagen. Livsformsanalysens oprindelige grundkategorier, som blev konceptualiseret tidligt i 1980'erne (Højrup, 1983a, 1983b, 1995), har skabt grobund for fortløbende forskningsprojekter baseret på livsforms- og samfundsanalyser (Buus, 2008; Højrup, 1999, 2003a, 2003b; Højrup \& Bolving, 2007). Samtidig har denne teoretiske optik været af betydning for menneskers selvforståelser og identitetsopfattelser gennem uddannelsesmæssige læreprocesser, faglig identitetsskabelse og politiske forankring og engagement. De tre grundkategorier er blevet videreudviklet i fortløbende forskningsprojekter og nye adækvate begreber er blevet introduceret synkront med den samfundsmæssige udvikling, der influerer på, skaber og forandrer livsformerne. Samtidig er professionsforskning - og etablering af nye professionskategorier - eskaleret gennem de sidste årtier (Hjort, $2001,2008)$. Buus (2008, s. 299) argumenterer for at: "Professionsbegrebet skjuler, at der er tale om, at der i en liberalistisk velfærdsstat udvikles velfærdslivsformer" - det vil sige at velfærdslivsformskategorien er underlagt en professionsorienteret verdensforståelse, hvori distinkt adskilte livsformskategorier usynliggøres. Der kan i forlængelse af dette argument rejses spørgsmål om hvorvidt professionsbegrebet skjuler livsformsbegrebet, eller om det er to begreber, der gensidigt kan supplere hinanden, fordi de i en velfærdsstatslig kontekst er uløseligt sammenvævede? Reelt er professionsbegrebet knyttet til et specifikt arbejdsfelt, en særegen professionsetik og konkrete faglige kompetencer og arbejdsopgaver, hvorimod livsformerne er overkategorier, der kan rumme flere forskellige professioner.

På baggrund af forskning i professionsidentitet, professionsudvikling og professionsetik 
bliver det tydeligt, at den humanitære livsform er stærkt knyttet til velfærdsprofessionerne og det affektive arbejde (Hjort, 2012, 2019). Overordnet karakteriserer kategorien professionelle i sundhedssektoren (læger, sygeplejersker og psykologer), i institutionsarbejde og uddannelsesområde (pædagoger og lærere), samt kommunale og statslige arbejdsområder (socialarbejdere og socialrådgivere). De mange forskellige uddannelsestrin og -former og tilknyttede titler, der også refererer til ovenstående arbejdsfelter, skal medregnes. Ledere og professionaliseringen af ledelse som arbejdsfelt vil også høre under kategorien, qua det stærke fokus der er på personligt, autentisk lederskab og evnen til at lede gennem relationer - hvilket medfører etiske fordringer og dilemmaer (Bøje \& Frederiksen, 2019; Hjort, Bøje, Raae, Ribers \& Stanek, 2018).

Selvom den faglige kerneviden, uddannelsernes længde og de fagområder, der arbejdes inden for, er vidt forskellige, så er der tale om professioner, der først og fremmest har arbejdet med andre menneskers ve og vel, opdragelse og helbredelse, at gøre. Man er et menneske, der samarbejder med mennesker, for og om mennesker. I denne sammenhæng har jeg også ophævet distinktionen mellem gamle og nye professioner, fuldgyldige eller semi-professioner (Krejsler, 2005), der i min optik er baseret på et samfunds-, værdi- og menneskesyn, som ikke fuldt indfanger betydningen af de velfærdsprofessioner, som bærer ens stor del af vores samfunds sammenhængskraft. Professionernes status, skal i denne, nutidige, sammenhæng anskues ud fra, hvilken betydning og værdi de har for mennesker og for samfundet. Således er den humanitære livsform som eksistenskategori på mange måder sammenvævet med en ny værdibaseret professionsforståelse, og centralt i denne kobling står etikken og professionsetikken. Værdimæssige spørgsmål om menneskers eksistens og fordringerne mod at tilstræbe det gode liv (jf, Højrup, 2003) bliver accentueret ved øgede konkurrencestatsparametre, der i højere og højere grad dikterer vores livsform.

\section{Nye livsformer}

Fordi statens strukturer og samfundet forandrer sig, etableres og forvandles livsformerne - de er henholdsvis betinget af staten og uløseligt sammenvævet med samfundsudviklingen. Dermed skabes bevæggrund for nye konceptualiseringer af den dynamik, der er mellem begreberne 'relation' og 'profession' (Moos, Krejsler \& Laursen, 2008) og dermed også af den professionelles faglige identitetsopfattelse, herunder hvad professionel integritet indebærer (Banks, 2010; Krejsler, 2005). Professionelle, der lever i velfærdslivsformerne, sammenføjer elementer fra lønarbejder-livsformen, den karrierebundne livsform, og den selvstændige livsform, fordi deres konkrete hverdagsliv overskrider de tre kategorier, hvilket ansporer til kritisk refleksion over professionernes placering i samfundet i en overordnet optik. Forskningen viser, at de tre klassiske livsformskategorier ikke fuldt ud indfanger kompleksiteten af professionelt velfærdsarbejde, fordi affektive arbejdsmiljøer har overskridende elementer på de menneskelige og psykiske niveauer, der er mellem arbejdsliv og privatliv, mens det imidlertid er underlagt lønarbejdets strukturer og betingelser (Ribers 2012). I forlængelse heraf er et relevant spørgsmål, om det "fordrer et sæt af velfærdslivsformer, der adskiller sig principielt fra de livsformer, der er knyttet til den kapitalistiske produktionsmåde" (Buus, 2008, s. 277). De nye livsformskategorier såsom relationsarbejder-livsformen, menneskearbejder-livsformen (Ribers, 2012), velfærdslivsformen (Buus, 2008) og den humanitære livsform belyser dermed identitetsmæssige aspekter, som er indlejret i de professionelles livsverdener. Velfærdsarbejde i 
konkurrencestaten er kendetegnet ved et nyt hyper-kompetitivt statssystem, der indebærer en dobbelthed mellem sammenhængskraft og konkurrencekraft (Christensen \& Højrup, 2007) - hvilket har indflydelse på menneskers muligheder for at agere og aspirere mod det gode liv.

Forskning i professionsidentitet og professionsetik peger på, at etisk perception og dømmekraft udvikles gennem livslang læring (Hugman, 2005), via det kollektive arbejdsfællesskab, som samtidig er knyttet til professionens særlige livsform. I relationsarbejde er en central problematik dikotomien mellem indlevelse og distance, hvilket kræver en særlig kompetenceudvikling eller balanceringen af den relationelle og menneskelige dimension i professionel praksis. Netop dette aspekt er en væsentlig del af både professionsetikken og den humanitære livsform. Etisk bevidsthed og moralsk perception, samt evnen til at navigere i og håndtere det affektive arbejde, er eksempler på nødvendige kompetencer. Professionelle er udøvere i et arbejdsfelt, som fordrer, at de besidder empati, herunder relationelle kompetencer såsom menneskelig indlevelse, samt socialvidenskabelig, psykologisk, medicinsk eller pædagogisk faglighed, kombineret med moralsk idealisme. Samtidig viser forskning, at arbejdslivet i sundhedssektor, dagtilbud, skole og institutionsmiljøer ofte konfronterer velfærdsprofessionelle med deres personlige grænser - der er med andre ord en flydende og ikke altid velfungerende grænsezone mellem arbejdsliv, fritid og familieliv. Studier af udvikling af professionsidentitet og etisk bevidsthed peger på, at livsformsanalysen er et:

"[v]oerdifuldt redskab til selvforståelse og diskussion af forholdet mellem arbejdsliv og privatliv, men at de tre klassiske kategorier ikke fuldt ud indfanger kompleksiteten i det paedagogiske arbejde med mennesker. [En paedagog] konstaterer på vegne af sin profession:
"Vi er jo karrierebundne, når det kommer til at udvikle os selv som redskaber i forhold til de mennesker, vi arbejder for", men påpeger samtidig det selvstoendige element $i$ visse arbejdsforhold og beslutningsprocesser, samt $i$ at håndtere de indtryk arbejdet giver. Endelig inddrager han, at han betragtes som en lønarbejder og er underlagt lønarbejdets strukturer" (Ribers, 2012, s. 115)

At finde den rette balance mellem de forskelligartede eksistensmodi i den humanitære livsform, har en central indflydelse på hvordan professionerne udvikler og definerer deres etos. Professionsbegrebet har i nogen grad udviklet sig fra at have karakter af en funktionalistisk term, gennem professionaliseringsprocesser af traditionelle fagdiscipliner inden for sundhedssektoren og socialområdet, og disse processer har været parallelle med "opbygningen af velfærdsinstitutioner baseret på liberalistiske velfærdsprincipper?" (Buus, 2008, s. 277).

Det skal anskues sådan, at udviklingen af den humanitære livsform er parallelt forløbende med udviklingen af professionerne i en epoke, hvor samfundet er præget af brydningsforhold mellem velfærdsstatens fællesgoder og de konkurrencestatslige parametre og styringsteknologier (Højrup, Jensen, Lidegaard, Buus \& Damsholt, 2012). De kategoriseringer, der er for livsformerne, er i nogen grad kvalitativt distinkte i forhold til kohærensen eller dikotomien mellem arbejdsforhold i det posttraditionelle samfund, samt betydningen af arbejdets værdi og skellet mellem arbejde og fritid for de individer, der er bærere af livsformerne. Empiriske studier indikerer imidlertid at livsformskategorierne ikke er statiske, men kan være overlappende, hvilket vil sige, at mennesker kan bære træk af forskellige livsformer samtidigt (Holm \& Jæger, 2007). På den baggrund er den humanitære livsform en adækvat kategori for fremtidige empiriske og 
teoretiske analyser af velfærdsprofessionelles livsmåder, vilkår og betingelser, samt forståelse af betydningsdannelser og eksistentielle meningskategoriseringer. Her vil jeg betragte den humanitære livsform - der som sagt har elementer fra flere livsformstræk - som en dynamisk og ikke statisk kategori. Kategorien er et analytisk perspektiv der tjener til at forstå de velfærdslivsformer, som bidrager til samfundets sammenhængskraft.

Min forskning har vist, hvordan velfærdsprofessionerne anvender livsformsanalysen undervejs i deres uddannelsesforløb som en platform for selvforståelse og identitetsskabelse (Ribers 2012). Livsformskategorierne kan bidrage til at forme deres professionelle identitet og perspektivere placeringen på arbejdsmarkedet, professionelt såvel som menneskeligt - hvor arbejdet i høj grad er forbundet med betydningsdannelser, der er forankret i en idealisme og humanisme - men hvor bagsiden er psykisk og emotionel overinvolvering i de mennesker, man arbejder med og for, hvilket kan medføre moral distress (Ribers 2018a, 2018b). Når vi ser på, hvordan relationsarbejdere gennem livslang læring udvikler professionel integritet og etisk perception, kan det ses i sammenhæng med de livsverdener, som udgør professionernes liv. Forskningen viser her, at der et sammenfald mellem professionelles personlige og arbejdsmæssige udfordringer og deres fokusområder gennem uddannelsesforløb, hvor kategorierne i livsformsanalysen også får en betydning for at forstå sig selv som velfærdsprofessionelle (Ribers, 2012).

Væsentlige forskningsanalyser ser således på de forskellige livsformer, der er knyttet til velfærdsstaten og velfærdsydelserne, og belyser hvorvidt man kan betragte velfærdsprofessioner som livsformer (Buus, 2008) - og det er her at professionsetikken og den humanitære livsform begynder at forbindes. Studier af velfærdsprofessionelles uddannelse og praksis giver perspektiver på, hvordan professionelle søger at manifestere humanismen i arbejdsmiljøer som er stærkt formet af samfundsmæssige rammer, økonomiske rationaler og politiske beslutninger - forhold som ikke altid understøtter de menneskelige værdier i arbejdslivet. At opretholde visionen om betydningen af det menneskelige i det institutionelle, afspejler et etisk ansvar, som sigter mod at skabe betingelser for det gode liv i organisatoriske sammenhænge. De etiske aspekter af relationsarbejde er imidlertid ikke givet, og det kræver mod, energi og indsigt at navigere $i$ et arbejdsfelt, der fordrer engagement og humanisme, men hvor arbejdsmiljøet ofte formes af institutionelt bårne kulturer og politiske dagsordner. Banks (2016) argumenterer for at en etisk forankret arbejdspraksis, der betragter professionelle som moralske agenter i forskellige kontekster, er et vigtigt modspil til regeringsbaseret management-mentalitet.

\section{Professionsetik, livsformer og arbejdsliv}

Der har været et centralt fokus på professionsetik gennem det seneste årti, både internationalt og i Danmark, og fagforbund for både pædagoger, lærere og socialrådgivere har etableret etiske værdigrundlag. Traditionelt set har lægerne haft lægeløftet, den hippokratiske ed, og også sygeplejeprofessionen har haft en stærk tradition for professionsetik. Med inspiration fra den europæiske menneskerettighedskonvention og på baggrund af en international udvikling af etiske retningslinjer (Banks, 2010, 2011) for professionelle i socialt arbejde, sundhedsfagene, pædagogisk arbejde og undervisning, har de danske fagforbund i samarbejde med forskere udviklet etiske grundlag, der kendetegner den særlige faglighed, ekspertise og professionelle etos, som er kernen i hver enkelt professions bidrag til velfærdssamfundet (Ribers 2016b). Dette accentuerede fokus på etik i arbejdslivet har 
betydning for mennesker, der er bærere af den humanitære livsform.

Professionsetiske grundlag er som udgangspunkt ikke ment som et styringsredskab, men derimod som et fælles fagligt fundament for værdibaseret refleksion, dialog og kontinuerlig udvikling af moralsk perception og dømmekraft gennem livslang læring. Dette er den positive etiske fordring, at professionelles arbejde bidrager til at skabe det gode liv for samfundets borgere, samtidig med at man engagerer sig $i$ at skabe et forsvarligt og sundt arbejdsmiljø. Etisk bevidsthed skal i dette perspektiv spire nedefra gennem demokratisk dialog og med fornemmelse for den kompleksitet, som arbejdslivet rummer og de begrænsninger og problemstillinger, som staten og de samfundsmæssige forhold betinger. Her får forholdet mellem arbejdsliv, privatliv og fritidsliv en betydning, hvilket er essentielt for, hvordan vi definerer og forstår livsformerne som eksistensmodi i staten. Både dansk og international forskning viser, at et professionsetisk kodeks kan få den modsatte funktion, i form af et top-down styringsredskab, der via New Public Management styringsteknologier, kan bruges til at regulere, kontrollere og sanktionere professionelle velfærdsarbejdere, hvis en professionsudøver ikke har handlet $\mathrm{i}$ overensstemmelse med gældende retningslinjer (Banks, 2011; Besley \& Peters, 2007; Ribers, 2016b). Denne risiko kan få alvorlige konsekvenser, fordi de arbejdsmæssige betingelser for danske professionelle, bliver vanskeligere og vanskeligere. Nedskæringer, effektivisering, kvalitetssikring, resultatkrav og øget dokumentation dikterer arbejdslivet og influerer på arbejdsmiljøet og dermed på de professionelles livsform.

Højrup (2003, s. 85) rejser spørgsmålet, om "[...] den professionaliserede velfærdsstatsform indebærer et sæt særlige velfærdslivsformer". Med et specifikt fokus på arbejdslivet, er det dermed væsentligt at diskutere velfærdsprofessionernes vilkår i konkurrencesta- ten, herunder hvordan politiske styringsmekanismer påvirker professionsudøvernes etos og arbejdsmiljø (Banks, 2011; Hjort, 2019; Hood \& Dixon, 2015; Høgsgaard, 2016). I forbindelse med dette spørgsmål, bidrager nyere forskning med interessante perspektiver på, hvordan velfærdsprofessionerne kvalificerer sig til arbejdet med mennesker $i$ et spændingsfelt mellem lønarbejde, relationsarbejde og vidensarbejde (Hjort, Kristiansen \& Barkholt, 2018; Moos, Krejsler \& Laursen, 2008) - med et nødvendigt fokus på professionsetik i spændingsfeltet mellem idealer og realiteter (Banks, 2010; Beckett 2007). Velfærdsprofessionerne har helt andre præmisser, både arbejdsmæssigt, økonomisk og med henblik på hvor der opnås mening, eller opstår konflikt, i deres samlede livsverden og i forhold til hvordan værdier, etiske ståsteder og meningskategorier udfordres.

\section{Velfærdslivsformer, det etiske pres og moral distress}

New Public Management styringsteknologier udfordrer dermed den sammenhængskraft, der er selve betingelsen for fornyelse, herunder samarbejdsevne og innovation $\mathrm{i}$ etableringen og opretholdelsen af et innovativt videnssamfund (Christensen \& Højrup, 2007). Midt i disse samfundsmæssige processer udfordres den faglige selvforståelse og forståelsen af forholdet mellem det personlige, det private og det professionelle, der i de professionelles livsverden ikke nødvendigvis opleves som entydigt afgrænsede områder. Det er i triaden mellem lønarbejde, vidensarbejde og relationsarbejde (Andersen \& Weber, 2009) at faglighed og den professionelle etos opstår. En pædagog, der deltager i et forskningsprojekt, reflekterer over sin etiske fordring på følgende måde:

"[d]et indeboerer en eller anden pligt til at holde sig selv ved lige, toenker jeg, og en pligt 
til at kigge indad på sig selv. Hvis vi skal arbejde med os selv i relationen med andre mennesker med os selv som voerktøj, så er vi jo også forpligtet til at følge med."

Professionsetiske dyder giver ikke en trinvis vejledning til handling i praksis, da de i det væsentlige beskæftiger sig med professionel integritet og faglig identitet snarere end handlingsdirektiver (Macfarlane, 2011). I den humanitære livsform er professionel integritet og etisk perception sammenvævet med subjektet, da man via sin person er sit eget arbejdsredskab. Sådanne komplekse forhold kan, hvis de for individet er sammenhængende med stærk idealisme og et højt etisk imperativ, resultere i moral distress - som er en intrapersonel psykisk belastning, der kan være forårsaget af et eksternt, statsligt og samfundsmæssigt pres på professionsudøvere (Ribers, 2018b).

Arbejdslivet i den humanitære livsform har overskridende sfærer i forholdet mellem arbejdsliv og privatliv, desuden falder professionernes arbejde ikke ind under den beskrivelse, at arbejdet er afgrænset og tjener det formål, at opretholde livet, hvorimod de meningsgivende aktiviteter i hverdagslivet skabes og opleves i fritiden. Velfærdsarbejde er i høj grad forbundet med meningsgivende elementer og rummer for nogle stadig aspekter af kaldstanken, hvor meningen findes i samarbejdet med og tjenesten for andre mennesker. Men på grund af de udefinerbare grænseforhold i relationsarbejde, på både et intrapersonelt og interpersonelt niveau, indebærer arbejdet risici for moral distress (se Oh \& Gastmans, 2015; Campbell, Ulrich \& Grady, 2016).

Det sidste årtis empiriske studier i professionsetikkens udvikling i Danmark viser at New Public Management har haft markant indflydelse på velfærdsprofessionelles udvikling og selvforståelse, hvilket kritisk set betragtes som en form for faglighed i for- vandling. Daginstitutionernes velfærdsarbejde, og de professionelle, som udfører det, eksemplificerer "hvordan borgere, ansatte og velfærdssamfund mødes i institutionaliserede rammer" (Krøjer, Nielsen \& Mogensen, 2017, s. 74). Paradoksalt nok kan professionsetikken blive det værn, der skal beskytte de professionelle mod at implodere under neoliberale politiske styringsstrategier, i en epoke hvor velfærdsarbejdet dikteres af finansielle stramninger og eklatant statslig regulering og kvalitetskontrol (Banks, 2011; Hood \& Dixon, 2015), hvilket øger det etiske pres på velfærdsprofessionerne og påvirker mennesker, der lever i den humanitære livsform. Etisk pres som begreb er dermed sociologisk og socialpsykologisk forankret og indfanger det ydre pres på professionelle, som staten og samfundet påfører dem - eller sagt på en anden måde, etisk pres kan resultere i moral distress, som i stedet erfares af individet som et professionelt og menneskeligt kompetencesvigt (Ribers, 2018b).

\section{Den professionelle etos}

Den humanitære livsform som eksistenskategori er sammenvævet med professionernes etik, og afspejler humanismens nødvendighed i en ny professionsforståelse. Velfærdsprofessionerne falder i tre kategorier, der samlet set er grundpiller i velfærdssamfundets strukturer og funktion: 1) de opbyggende professioner, der varetager dannelse, hvilket er fagfolk med kompetence i pædagogik, psykologi, undervisning og læring, 2) de helende professioner, der varetager opretholdelse, som er fagfolk med ekspertise i medicin, sygepleje og teologi, og 3) de regulerende professioner, der agerer med intervention, hvilket er professionelle med faglig videns-forankring inden for jura, social indsats og politi. Alle disse professioner har menneskers livsveje som deres primære genstandsfelt og det fordrer en anerkendelsen af værdien og kom- 
pleksiteten i de krævende former for arbejde, som er bærende for samfundets borgeres ve og vel og udviklingsmuligheder. Samtidig er alle disse faggruppers virke forankret i professionsetiske værdigrundlag eller retningslinjer. Derfor er de professionelle, som udgør arbejdsstyrken i de tre professionskategorier, alle omfattet af, eller indlejret i den humanitære livsform. Dette perspektiv er på den lange bane determinerende for fremtidens samfunds strukturelle og menneskelige sammenhængskraft.

Det er imidlertid vigtigt at fremhæve, at der er en væsentlig forskel på professionsetiske retningslinjer, etiske grundlag og et etisk kodeks og professionelles udvikling af etisk perception og dømmekraft. Arbejdslivet er et dynamisk felt, hvori professionelle skal agere med en bevidsthed om, hvordan deres handlinger påvirker andre, og hvorvidt de bidrager til at skabe et sundt arbejdsmiljø. Dette gøres ikke ved blindt at følge etiske retningslinjer - de kan positivt set danne grobund for refleksion, erkendelse og læring - men skal integreres som faglig viden og professionel integritet, der omsættes til handling i praksis. Moralsk perception er ikke synonymt med en etisk algoritme, der styrer individets handlinger, derimod kan faglige dyder, defineret som professionelle karakteregenskaber, blive udviklet og udvist i uddannelse og praksis (Macfarlane, 2011). Grundlæggende er den professionelle etos forankret i værdier, som kan bære eller brydes; eksempelvis er tillid og troværdighed baseret på gensidighed mellem parter, som tror på, at den anden part vil handle velvilligt og med gavnlige hensigter (Grimen, 2008; Gronn, 2011). Man kan anskue det sådan, at der er centrale gensidige forudsætninger og forventninger, mellem staten og de humanitære livsformers eksistens:

"Livsformens eksistensberettigelser skabes og reproduceres gennem de former for lovgivning, der baner vej for dens adgang til befolkningen på den ene side og befolkningens krav om at få stillet viden til rådighed og modtage autentisk, individuel omsorg på den anden." (Buus, 2008, s. 290)

Velfærdsarbejdet er statsligt styret og organiseret, og arbejdspladser præges ofte af modstillede ideologier og politiske strategier, og der er ikke altid tid, plads eller rum til at skabe den nødvendige tillid i de menneskelige relationer.

Følelser og menneskets viljekraft spiller en central rolle i udvikling af etisk perception, i og med at fagfolk ikke alene styres af rationalitet eller teoretiserede etiske begrundelser. Den livslange læring af professionelle kompetencer og etisk bevidsthed foregår kontinuerligt og raffineres gennem erfaring og påvirkning af andre - specifikt professionelle rollemodeller (Macfarlane, 2011). Det som kendetegner professionelle, hvis eksistensmodus er den humanitære livsform, er deres arbejdes uadskillelige tilknytning til et velfærdssamfund, som er underlagt, hvad der i dag betegnes som enten konkurrencestaten, hybrid-staten eller konglomeratstaten (Hjort et al., 2018). Det er overvejende offentligt ansatte, der er tale om ved denne kategori, selvom der i hver faggruppe er mulighed for, at en del er selvstændige. Det som kendetegner den humanitære livsform er, at den er båret af professionelle, som qua deres arbejde med andre mennesker, bærer et stort ansvar, både for de mennesker, de arbejder med og for, men også i forhold til de arbejdspladser og det arbejdsmiljø, som de er integreret i og medskabere af (Sugrue \& Solbrekke, 2011). På denne måde er professionsetikken ikke blot et anliggende for individet, men i høj grad et kollektiv, organisatorisk og samfundsmæssigt anliggende (Ribers, 2016a). Professionsetik er ikke blot et spørgsmål om moralsk dømmekraft hos den enkelte, det er et komplekst mønster af sammenvævede og modsatrettede 
brydningsflader, værdier og perspektiver, som udspiller sig i en samfundsmæssig og institutionel kontekst. Der er dermed flere grænseoverskridende fænomener forbundet med den humanitære livsform: man er sit eget arbejdsredskab, man tager arbejdet med hjem, man har skiftende arbejdstider i institutions- og sundhedssektoren, og man bærer et stort, og ofte direkte, ansvar for andre menneskers liv, opdragelse og helbredelse. Samtidig er professionelle underlagt et stort arbejdspres på grund af statens besparelser og effektivisering - hvilket resulterer i en nedprioritering af den konkrete tid, som kunne være i mødet mellem de professionelle og borgerne - og dermed udfordrer de ansatte på deres grundlæggende værdier og værdighed. Den professionelle etos er under pres og det skaber dønninger ind i den humanitære livsform.

\section{Livsformer, velfærdssamfund og konkurrencestat}

Når man ser på den sammenvævede dynamik mellem det personlige og det professionelle for fagfolk i velfærdsarbejdsstyrken - at man i kraft af relationsarbejdets karakter er sit eget arbejdsredskab som menneske - øges sårbarheden for etisk pres og beslægtede følger såsom moral distress og udbrændthed. Dette er et vigtigt fokuspunkt i forskning, der omhandler livsformerne. Det vil sige, at de arbejdsmiljømæssige forhold og generelle livsvilkår, som kendetegner mennesker i den humanitære livsform, udfordres, og det der i et aristotelisk perspektiv er etikkens helt basale formål, at tilstræbe det gode liv, sættes under pres. Hjort (2019) argumenterer for, at alle velfærdsarbejdere er placeret i en paradoksal eller modstridende situation. De professionelle får nye magtpositioner i kraft af deres faglige kompetencers betydning for velfærdssamfundet, samtidig bliver de genstand for nye magtkampe - og resultatet af disse magtspil er vigtige ikke kun for professionerne, men for fremtidens nordiske samfund (Hjort, 2019).

Med en kritik af neoliberale styringsformer advokerer Banks (2011) for at professionelle må rejse sig i fælles kamp, og med udgangspunkt i professionsetikkens fundamentale værdisæt, styrke deres faglige værd og anseelse - med andre ord, manifestere den humanitære livsforms særegne islæt og betydning. Spørgsmålet er, hvordan det bedst gøres, og hvordan professionelle udrustes til at forstå, håndtere og konkretisere de problemer, som de står overfor. Min forskning viser positive resultater af aktionsforskningsbaserede etik-uddannelser, der indarbejder etisk refleksion og supervision og dermed skaber læringsmiljøer, som giver mulighed for at processere etiske dilemmaer og problematiske arbejdsmiljøforhold (Ribers, 2018a, 2018b).

Forskningsprocesserne har vist, at aktionsforskning i uddannelse og arbejdsliv, kan være et stærkt bidrag til at skabe bevidsthed om etik og om kompleksiteten ved at være i den humanitære livsform. Velfærdsprofessionelle kan gennem kollegial dialog og kritisk refleksion bidrage med et emancipatorisk element i professionelles selvforståelse og virke (Ribers, 2018b; se også Kondrup 2017). Gennem aktionsforskningens innovative udviklings- og læreprocesser, som kan bygge bro mellem teori og praksis, idealer og realiteter, kan professionelles etiske autonomi og livsformsidentitet skærpes. I og med at den skandinaviske model for aktionsforskning i mange år har bidraget væsentligt til velfærdsprofessionernes og livsformernes udvikling - via demokratiske innovationsprocesser i velfærdsinstitutioner, velfærdsarbejdet og samfundet (Gunnarsson, Hansen, Nielsen \& Sriskandarajah, 2016) - da får aktionsforskningen en central position i forhold til at styrke velfærdsprofessionernes placering, status og vilkår. Der er dermed et øget incitament til at arbejde forskningsbaseret med 
de problematikker, der eksisterer som følge af det etiske pres, der opstår for de professionelle i dynamikken mellem staten og den humanitære livsform.

Der er i et arbejdslivsmæssigt perspektiv knyttet professionsetiske dimensioner og dilemmaer til en specifik livsform. De mennesker som er bærere af livsformerne, skaber menings- og betydningsdannelser, forankret i et værdisystem, ud fra hver deres begrebsunivers og de ideologibærende livsformer eksisterer via deres selvkoherente helhedsforståelse af livsverdener (jf. Holm \& Jæger, 2007). Fordi livsformerne dannes som eksistensformer i samfundet i kontinuerlig relation til udviklingen af statsapparatet, er de både påvirkelige og sårbare, men også modstandsdygtige i forhold til at konstituere de værdier, den etik og den humanisme, som for hver livsform kendetegner det gode liv. Den etos som er grundstenen i en livsform udfordres at statsligt initierede forandringer, der påvirker livsvilkår og arbejdsmiljøet, og professionelle, som er bærere af den humanitære livsform, udfordres på deres grundlæggende etiske standpunkter.

Hjort (2019, s. 385) rejser spørgsmålet, om vi ønsker at opretholde og videreføre den klassiske nordiske velfærdsindsats for at opnå social retfærdighed og lighed i samfundet fænomener som kendetegner og konsoliderer det gode liv. Netop dette er et af de mest centrale omdrejningspunkter i forståelsen og anerkendelsen af den humanitære livsform. Christensen \& Højrup (2007, s. 433) advokerer for, at det i Danmark er afgørende at bevare samfundets sammenhængskraft, fordi netop denne sammenhængskraft, er vores konkurrencekraft. Man kan argumentere for, at etisk pres på professionerne er nedbrydende for sammenhængskraften - eller omvendt, at øget anerkendelse af de humanitære livsformers unikke betydning og nødvendighed for velfærdssamfundets beståen - er en styrkelse af de kræfter som skaber sammenhæng, for samfundet og de eksistensformer, som velfærdsprofessionelle lever under. Hjort (2019) pointerer, at hvis omdannelsen af det nordiske offentlige arbejdes kvaliteter til nye konkurrencemæssige beføjelser i en global affektiv økonomi skal lykkes, bliver professionernes arbejde af stadigt større samfundsmæssig betydning. Set i et samfundsmæssigt perspektiv, vil det være af tilsvarende stor betydning, at politikere, beslutningstagere, og samfundets øvrige borgere på et meget fundamentalt niveau øger respekten for de humanitære livsformers eksistens, arbejde og bidrag til sammenhængskraften i velfærdssamfundet - og samtidig udvikler forståelse og anerkendelse for den kompleksitet som velfærdsarbejdet indebærer.

Den humanitære livsform som kategori, er opstået på baggrund af uddannelsesetnografisk forskning, aktionsforskningsprocesser og kvalitative studier af velfærdsprofessionelles identitetsdannelse, uddannelse og arbejdsliv. Den er derved etableret i spændingsfeltet mellem induktive forskningsperspektiver og det deduktive eksisterende teoretiske perspektiv, som ligger i livsformsanalysen. På baggrund af forskningsprocesserne, er det mit indtryk, at det vil være meningsfuldt at fortsætte med yderligere empirisk forskning, der belyser de mange komplekse facetter af den humanitære livsforms eksistens i velfærdssamfundet. En videre teoretisk diskussion og præcisering af begrebet vil også være interessant, både i forhold til kategoriens placering i livsformsanalysen, men også i forhold til det stigende fokus, der er på professionsudvikling, og ikke mindst i forhold til de centrale samfundsog professionsetiske dimensioner, som er indlejret i velfærdens opretholdelse, eller afvikling, i vores nutidige højforanderlige samfund. Professionaliseringen af faggrupper forstærker monopolet på ekspertise inden for et givent fagområde, og accentuerer de specifikke etiske kendetegn, som definerer en profession. Dermed er dynamikken mel- 
lem livsformerne som overordnede sociale formationer og professionerne som grupper af specifikke faglige agenter i samfundet et relevant felt for videre forskning, med

\section{RefERENCER}

Andersen, R. \& Weber, K. (2009). Profession og praktik. Frederiksberg: Roskilde Universitetsforlag.

Banks, S. (2010). Integrity in Professional Life: Issues of Conduct, Commitment and Capacity. British Journal of Social Work, 40(7), 2168-2184. doi:10.1093/bjsw/bcp152.

Banks, S. (2011). Ethics in an Age of Austerity: Social Work and the Evolving New Public Management. Journal of Social Intervention: Theory and Practice, 20(2), 5-23. doi:10.18352/jsi.260.

Banks, S. (2016). Everyday ethics in professional life: social work as ethics work. Ethics and Social Welfare, 10(1), 35-52. DOI: 10.1080/17496535.2015.1126623.

Beckett, C. (2007). The Reality Principle: Realism as an Ethical Obligation. Ethics and Social Welfare, 1(3), 269-281. doi.org/10.1080/17496530701602790.

Besley, T. (A.C.) \& Peters, M. A. (2007). Subjectivity $\&$ Truth - Foucault, Education and the Culture of Self. New York: Peter Lang.

Buus, H. (2008). Indretning og efterretning. Rockefeller Foundations indflydelse på den danske velfoerdsstat 1920-1970. København: Museum Tusculanums Forlag.

Bøje, J. D. \& Frederiksen, L. F. (2019). Leaders of the profession and professional leaders. School leaders making sense of themselves and their jobs. International Journal of Leadership in Education. https://doi.org/10.1080/136031 24.2019.1591515

Campbell, S. M., Ulrich, C. M. \& Grady, C (2016). 'A Broader Understanding of Moral Distress.' The American Journal of Bioethics, 16(12), 2-9. doi:10.1080/15265161.2016.1239782.

Christensen, L. R. (1988). Livsformer i Danmark. København: Samfundsfagsnyt.

Christensen, S. \& Højrup, T. (2007). 'Afslutning: Det nærværendes fravær'. I Højrup, T. \& et kontinuerligt fokus på de værdimæssige spørgsmål, problemstillinger og udfordringer, som vedvarende berører aspirationen mod eudaimoni - at skabe det gode liv.

Bolving, K. (Red.), Velfoerdssamfund - velfoerdsstaters forsvarsform? (s. 413-435).. København: Museum Tusculanums Forlag .

Grimen, H. (2008). Profesjon og tillit. I A. Molander \& L. I. Terum (Red.), Profesjonsstudier (s. 197-215). Oslo: Universitetsforlaget.

Gronn, P. (2011). Risk, trust and leadership. In Sugrue, C. \& Solbrekke, T. D. (Eds.), Professional Responsibility - New Horizons of Praxis (s. 89 - 101). New York: Routledge.

Gunnarsson, E., Hansen, H. P., Nielsen, B. S. \& Sriskandarajah, N. (Red.) (2016). Action Research for Democracy: New Ideas and Perspectives from Scandinavia. New York: Routledge.

Hjort, K. (2001). Moderniseringen af den offentlige sektor. Frederiksberg: Roskilde Universitetsforlag.

Hjort, K. (2008). Professionaliseringen af den offentlige sektor. Frederiksberg: Roskilde Universitetsforlag.

Hjort, K. (2012). Det affektive arbejde. Frederiksberg: Samfundslitteratur.

Hjort, K. (2019). Affective Work and Access to Excellence - Reorganizing Nordic Welfare. Advances in Social Sciences Research Journal, 6(1), 377-387. DOI:10.14738/assrj.61.6062.

Hjort, K., Bøje, J. D., Raae, P. H., Ribers, B. \& Stanek, A. H. (2018). En god (nok) leder: professionalisering af skoleledelse. København: Forlaget Werkstatt.

Hjort, K., Kristiansen, A. \& Barkholt, N. C. (Red.) (2018). Profesjonsetikk - Velferdsarbeid for og med mennesker. Oslo: Gyldendal Norsk Forlag.

Holm, A. \& Jæger, M. M. (2007). 'Livsformer i Danmark: udbredelse og udviklingstendenser 1981-2005'. Socialpolitik og velfærdsydelser - arbejdspapir 08:2007. København: Social Forsknings Instituttet. [Tilgået 15.03.2019 via 
https://pure.au.dk/ws/files/537/AP08_2007. pdf]

Hood, C. \& R. Dixon. (2015). What We Have to Show for 30 Years of New Public Management: Higher Costs, More Complaints. Governance: An International Journal of Policy, Administration, and Institutions, 28(3), 265-267. doi:10.1111/ gove.12150.

Hugman, R. (2005). Exploring the Paradox of Teaching Ethics for Social Work Practice. Social Work Education, 24(5), 535-545.

Høgsgaard, D. (2016). Det muliges kunst. Om betingelserne for det tværsektorielle samarbejde i et New Public Managementorienteret sundhedsvæsen. Tidsskrift for Arbejdsliv, 18(3), 64-80.

Højrup, T. (1983a). Det glemte folk, livsformer og centraldirigering. Hørsholm: Institut for Europæisk Folkelivsforskning Statens Byggeforskningsinstitut.

Højrup, T. (1983b). The concept of life-mode, a form-specifying mode of analysis applied to contemporary Western Europe (Ethnologia Scandinavica 1983). Arlöv: Berlings.

Højrup, T. (1995). Omkring livsformsanalysens udvikling (Stats- og livsformer 1). København: Museum Tusculanums Forlag.

Højrup, T. (1999). Dannelse og dansk identitet - livsformer og nationalitet. Undervisningsministeriet: Tidsskriftet Uddannelse, 5, 99.

Højrup, T. (2003a). Livsformer og velfoerdsstat ved en korsvej? København: Museum Tusculanums Forlag.

Højrup, T. (2003b). State, Culture, and Life-Modes. The Foundations of Life-Mode Analysis. Burlington, Vt: Ashgate.

Højrup, T. (2013). Life Mode Analysis - the coming in to being. SAXO-Institute, University of Copenhagen. https://lifemodes.ku.dk/about/Life_ Mode_Analysis_-_the_coming_into_being. pdf [Tilgået 19-03-2019].

Højrup, T. \& Bolving, K. (Red.) (2007). Velfoerdssamfund - velfoerdsstaters forsvarsform? København: Museum Tusculanums Forlag.

Højrup, T., Jensen, U. J., Lidegaard, B., Buus, H. \& Damsholt, T. (2012). Dannelsens Dialektik: Etnologiske udfordringer til det glemte folk. (2 udg.)
København: Museum Tusculanum. Stats- og livsformer, Bind. 4.

Krejsler, J. (2005). Professions and their Identities: How to explore professional development among (semi-)professions. Scandinavian Journal of Educational Research, 49(4), 335-357, DOI: 10.1080/00313830500202850.

Kondrup, S. (2017). Relationen mellem arbejde og læringsidentitet - et bud på en kvalitativ analysemodel. Tidsskrift for Arbejdsliv, 19(4), 55-70.

Krøjer, J. \& Dupret, K. (2015). Moral Literacy in Technological Care Work. Ethics and Social Welfare, 9(1), 50-63. DOI: 10.1080/17496535.2014.938672

Krøjer, J. \& Lehn-Christiansen, S. (2016). Moralske kroppe - etik, tillid og kropspraksisser i sundhedsprofessionelles arbejde. Tidsskrift for Arbejdsliv, 18(2), 41-53.

Krøjer, J., Nielsen, S. B. \& Mogensen, K. (2017). Generationsspecifikke forskelle mellem pædagogers faglighed. Tidsskrift for Arbejdsliv, 19(4), 74-88.

Macfarlane, B. (2011). Teaching, integrity and the development of professional responsibility: Why we need pedagogical phronesis. In Sugrue, C. \& Solbrekke, T. D. (Eds.), Professional Responsibility - New Horizons of Praxis (s. 72 86). New York: Routledge.

Moos, L., Krejsler, J. \& Laursen, P. F. (Red.) (2008). Relationsprofessioner - Loerere, Poedagoger, Sygeplejersker, Sundhedsplejersker, Socialrådgivere og Mellemledere. København: Danmarks Pædagogiske Universitetsforlag.

Oh, Y. \& Gastmans, C. (2015). Moral Distress Experienced by Nurses - A Quantitative Literature Review. Nursing Ethics, 22(1) 15-31. doi:10.1177/0969733013502803.

Ribers, B. (2012). Den etiske udfordring - perspektiver på konstituering af etisk bevidsthed i professionelt relationsarbejde. Ph.d.-afhandling. Institut for psykologi og uddannelsesforskning. Roskilde Universitet.

Ribers, B. (2016a). 'Mellem etiske perspektivskift og intervention - om ledelsesmæssig håndteringskompetence og uddannelsesforskning' (s.183-204). I J. D. Bøje \& D. R. Hansen (Red.), 
Mellem ledere - uddannelsesledelse som problem eller svar? Aarhus: Klim.

Ribers, B. (2016b). 'Etisk pres: Socialarbejdere i spændingsfeltet mellem New Public Management og den professionelle etos'. Social Årsrapport 2016: Den danske velfoerdsmodel -udvikling eller afvikling? Nr. 17. København: CASA, Analyse \& Tal og Socialpolitisk Forening.

Ribers, B. (2018a). 'The Plight to Dissent: Professional Integrity and Ethical Perception in the Institutional Care Work of Early Childhood
Educators' European Early Childhood Education Research Journal, 26(6), 893-908. DOI: 10.1080/1350293X.2018.1533707.

Ribers, B. (2018b). 'Etiske Cirkler: professionskvalificering mellem etisk pres og professionel integritet' (s. 134-157). I Hjort, K., Kristiansen, A. \& Barkholt, N. C. (Red.). Profesjonsetikk: Velferdsarbeid for og med mennesker. Oslo: Gyldendal Norsk Forlag.

Sugrue, C. \& Solbrekke, T. D. (Eds.) (2011). Professional Responsibility - New Horizons of Praxis. New York: Routledge.

Bjørn Ribers, cand.mag., ph.d., ekstern lektor Syddansk Universitet e-mail: ribers@sdu.dk 